\title{
Tanssin mahdollisuudet aivoverenkiertohäiröiden kuntoutuksessa: Kirjallisuuskatsaus
}

Camilla Björklund and Hanna Pohjola

\section{ABSTRACT}

Stroke affects one in six people in Finland and is the third most common cause of death. Strokes can cause changes in physical, mental and social functioning. All functional disorders can be affected by rehabilitation: physical treatment is a key part of active rehabilitation after a stroke.

In this article, the known effects of dance on stroke are gathered together on the basis of a literature review and discussed in the context of dance pedagogy. The data was systematically retrieved from the PubMed, CINAHL and Arsca databases. Eleven research articles meeting the search criteria were selected. Content analysis was used to analyze the data. The results of the research literature analysis indicated that dance is suitable for stroke rehabilitation: it promotes psychological, cognitive and physical functioning. The results spoke in favour of dance intervention supporting and developing a relationship to one's own altered body and self-esteem, as well as enabling social relationships. In addition, dance improves one's mental state. Therefore, these factors suggest that dance could meet the need for a new form of neurological rehabilitation therapy.

\section{TIIVISTELMÄ}

Aivoverenkiertohäiriöön (AVH) sairastuu Suomessa joka kuudes ihminen, ja se on kolmanneksi yleisin kuolinsyy. AVH voi aiheuttaa muutoksia fyysisessä, psyykkisessä ja sosiaalisessa toimintakyvyssä. Kaikkiin toimintakyvyn häiriöihin voi vaikuttaa kuntoutuksella: keskeisessä osassa aivohalvauksen aktiivista kuntoutusta on liikunta.

Tässä artikkelissa tarkastellaan tanssipedagogiikan näkökulmasta tanssin vaikutuksia AVH-kuntoutujiin kirjallisuuskatsauksen avulla. Aineisto haettiin systemaattisesti PubMed-, Cinahl-ja Arsca-tietokannoista. Mukaan valikoitui 11 hakukriteerit täyttävää tutkimusartikkelia. Aineiston analysoinnissa käytettiin sisällönanalyysiä. Tutkimustuloksista ilmeni tanssin olevan soveltuva AVH-kuntoutujille: se edistää psykologista, kognitiivista ja fyysistä toimintakykyä. Tulokset puhuivat sen puolesta, että tanssi-interventio tukee ja kehittää suhdetta omaan muuttuneeseen kehoon ja itsepystyvyyteen sekä mahdollistaa sosiaalisia suhteita. Lisäksi se kohentaa mielialaa. Nämä tekijät voivat puhua sen puolesta, että tanssi voisi vastata uuden terapiamuodon tarpeeseen neurologisessa kuntoutuksessa. 


\section{Tanssin mahdollisuudet aivoverenkierto- häiröiden kuntoutuksessa: Kirjallisuuskatsaus}

Camilla Björklund and Hanna Pohjola

\section{Johdanto}

Tanssinopettajan työnkuva moninaistuu samalla, kun tanssin kenttä ulottuu yhä laajemmalle yhteiskunnassa. Tanssi ja tanssiminen näkyvät enemmän eri väestöryhmien joukossa kuten esimerkiksi erilaisissa organisaatioissa, kouluissa ja hoitolaitoksissa (ks. esim. Jaakonaho 2017; Lehikoinen 2019; Pohjola ym. 2020). Osallistuminen tanssiin on kulttuurinen oikeus (Lehikoinen 2017). Tanssin soveltava käyttö myös neurologisten sairauksien kuntouttamisessa on ajankohtainen aihe (Lossing ym. 2017): kiinnostus on kohdistunut erityisesti Parkinsonin tautiin (Sharp ja Hewitt 2014; Shanahan ym. 2015). Tanssin soveltava käyttö aivoverenkiertohäiriöiden (AVH) kuntouttamisessa on sen sijaan vielä varsin tuore aihe. Tämän artikkelin tarkoituksena on (1) koota yhteen tieteellisesti tutkittua tietoa tanssin vaikutuksista AVH-kuntoutuksessa ja (2) pohtia tutkimustuloksia tanssipedagogisesta näkökulmasta.

$\mathrm{AVH}$ on yhteisnimitys aivoverisuonten tai aivoverenkierron sairauksille. Oirekuvaan kuuluvat aivoinfarkti, aivojensisäinen verenvuoto, lukinkalvonalainen verenvuoto tai aivolaskimoiden tromboosista johtuva aivotoimintojen häiriö (Käypä hoito -suositus 2020). TIA (engl. transient ischemic attack) on puolestaan lyhenne tilapäiselle aivoverenkiertohäiriölle, joka on kohtausmainen oirekuvaltaan ilman pysyvää kudosvauriota. Pysyvän vaurion aiheuttavia ovat sen sijaan aivoinfarkti tai aivoverenvuoto. AVH voi aiheuttaa monin tavoin muutoksia fyysisessä, psyykkisessä ja sosiaalisessa toimintakyvyssä. Seuraukset vaihtelevat yksilöllisesti ja ovat riippuvaisia vaurioalueen sijainnista ja laajuudesta. Halvausoireet, tuntopuutokset, kielelliset häiriöt ja henkisen toimintakyvyn ongelmat kuuluvat näihin oireisiin (Aivoliitto 2020). Lisäksi aivohalvaus vaikuttaa usein askellukseen, tasapainoon ja kehon nivelten liikkuvuuteen (Patterson 2018a, 2018b). Vaikeuksia voi ilmetä myös esimerkiksi jokapäiväisissä toiminnoissa, kuten kirjoittamisessa, lukemisessa, muistamisessa, hahmotuksessa sekä ajattelussa ja päättelyssä (Käypä hoito -suositus 2020). Myös masennus on yleistä (Robinson ja Jorge 2016).

Liikunta on keskeisessä osassa neurologisten sairauksien kuntoutusta, myös AVHssa. Viime vuosina perinteisen fysio- ja toimintaterapian ohella on kiinnostuttu myös taiteiden vaikutuksista neurologisessa kuntoutuksessa. Esimerkiksi tanssin vaikutuksia on tutkittu neurologisissa sairauksissa tähän mennessä eniten Parkinsonin tautia sairastavilla, joilla sekä kävely- että tasapainokyky ovat kehittyneet paremmin tanssituntien kuin fysioterapian jäljiltä (Gregor ym. 2020, 2). Vaikutuksia on löydetty myös toiminnallisessa liikkuvuudessa (Rios ym. 2015, 182) ja kohentuneessa mielialassa (Lewis ym. 2016). Tanssituntien on todettu kehittävän perinteistä kuntoutusta enemmän myös toiminnanohjausta ja edistävän luovan sosiaalisen tuen tunnetta sitä tukevassa yhteisössä (Gregor ym. 2020, 2). On myös ehdotettu, että tanssi voi tarjota ainutlaatuisen fyysisen toimintamenetelmän edistämään neuroplastisuutta (Dhami ym. 2015, 6).

\section{Metodologia Aineiston valintaprosessi}

Artikkelin aineistonkeruussa käytettiin kuvailevaa kirjallisuuskatsausta (ks. Salminen 2011; Kangasniemi ym. 2013), joka pyrkii antamaan kokonaiskuvan 
olemassa olevasta asiakokonaisuudesta. Tiedonhaussa käytettiin PubMed-, Cinahl- ja Arsca-tietokantoja. Tiedonhakua johti aiemmin asetetut tutkimuskysymykset, jotka olivat muodostettu PICo-menetelmän (Hotus n.d.) avulla. Hakusanoilla «cerebrovascular disease dance», «rehabilitation stroke dance» ja «stroke dance intervention» tehtiin ensin testihaku, jotta löydettäisiin yhdistelmä, jolla löytyisi tarpeeksi laaja otanta, joka sisältäisi kaikki aiheeseen liittyvät relevantit julkaisut. Varsinainen aineistohaku suoritettiin huhtikuussa 2020 PubMedsta ja Cinahlsta sanoilla «stroke dance», kun taas Arsca-tietokannasta rajaus täytyi tehdä tarkemmin sanoilla «stroke dance rehabilitation intervention», koska tämä tietokanta sisältää laajalti aineistoa. Työssä käytettiin pääasiallisesti luotettavia tietokantoja: luotettavuutta lisäsi myös aineiston haun rajaus uusimpiin tieteellisiin vertaisarvioituihin artikkeleihin.

Katsaukseen haettu aineisto oli suomen- ja englanninkielistä ja se koostui vertaisarvioiduista tieteellisistä artikkeleista, jotka on julkaistu vuosina 2010-2020. PubMed-tietokannasta löytyi kyseisillä hakukriteereillä 52 artikkelia, Cinahlsta kuusi ja Arscasta 326 (ks. kuvio 1). Tämän jälkeen poissuljettiin artikkelit, jotka eivät vastanneet otsikon perusteella tutkimuskysymyksiin tai ne olivat valikoituneet jo aiemmasta tietokannasta. Jäljelle jäi tässä vaiheessa 14 artikkelia (Pubmedista kahdeksan ja Arscasta kuusi kappaletta). Cinahl -tietokannasta ei löytynyt asetetun kriteeristön mukaisia artikkeleita. Tässä vaiheessa valittujen artikkeleiden relevanssi määritettiin lukemalla ensin johdanto ja yhteenveto, jonka jälkeen jäljelle jäi yhteensä yhdeksän artikkelia (PubMed, seitsemän kpl; Arsca kaksi kpl). Viimeisenä luettiin vielä koko tekstit, jonka jälkeen valintakriteerit täyttyivät yhdeksässä artikkelissa. Lisäksi erään tieteellisen tutkimuksen lähdeluettelosta valikoitui mukaan yksi artikkeli ja mukaan otettiin myös kriteerit täyttävä tieteellinen tutkimusartikkeli. Katsaukseen valikoitui lopulta siis 11 tieteellistä tutkimusta. Katsauksessa käytettiin

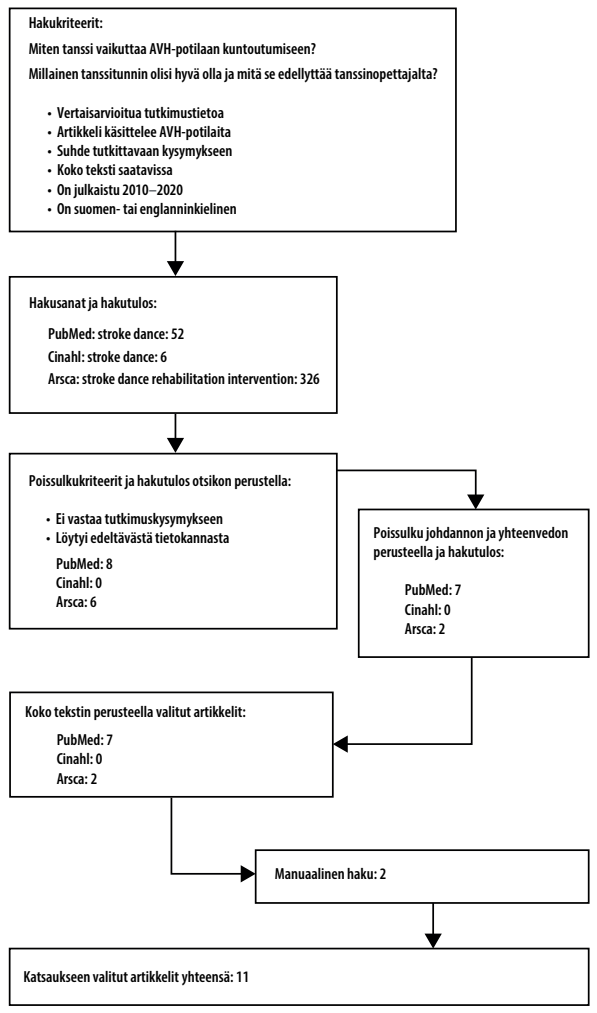

Kuvio 1. Aineiston hakukriteerit ja bakuprosessin eteneminen.

taulukointia avuksi hakuprosessin etenemisessä. Hakukriteerit ja hakuprosessin eteneminen on esitetty kuviossa 1.

\section{Aineiston analyysi}

Aineiston analysoinnin ja järjestämisen apuvälineenä käytettiin sisällönanalyysiä (Braun ja Clarke 2006; Tuomi ja Sarajärvi 2018). Aineiston pelkistämisen, ryhmittelyn ja teoreettisten käsitteiden luomisen apuna käytettiin lisäksi taulukointia (ks. taulukko 1). Analyysi aloitettiin käymällä artikkelit läpi ja poimimalla niistä ensin taulukoihin otsikko, tekijät, julkaisuvuosi, tutkimusmenetelmät, toteuttamismaa, tutkittavien ikä ja sukupuoli sekä AVHn sairausvuodet. Keskeiset tulokset ja johtopäätökset koottiin erilliseen 
taulukkoon. Aineistojen data luokiteltiin ensin kahden pääluokan alle tutkimuskysymysten mukaan. Kullakin artikkelilla oli oma väri, jotta lähteet pysyivät eroteltuina ja jotta tietoa päästiin vertailemaan keskenään. Yläluokkien alle jaettiin sen jälkeen alaluokat. Näin kerättiin tutkimuksen kannalta olennaisin tieto.

Tutkimukseen valikoitui 11 tutkimusartikkelia, joista kolme oli kvalitatiivista ryhmäinterventiota, kolme kirjallisuuskatsausta, yksi kvantitatiivinen tutkimus, kaksi kvalitatiivista tapaustutkimusta ja kaksi tapaustutkimusta. Tutkimuksista seitsemän oli toteutettu Kanadassa, yksi Ruotsissa, yksi Kiinassa, yksi USAssa ja yksi Suomessa. Tutkimusten kohderyhmistä yksi käsitteli subakuutin aivohalvauksen vaihetta ja viisi kroonista aivohalvausta. Lisäksi kaksi kohdentui aivoiskemiaan. Tutkimusmenetelminä käytettiin tanssi-interventiota, haastattelua (so. yksilö- ja focus group -haastattelu) ja stimuloitua muistiin palauttamismenetelmää. Kirjallisuuskatsauksien teemoja olivat kognitiivisen ja fyysisen kuntoutuksen integrointi neurologisissa sairauksissa (mukaan lukien aivohalvaus), tanssin vaikutukset neurologisissa sairauksissa (mukaan lukien aivohalvaus) ja terveydenhuollon laadun parantaminen motorisessa kuntoutuksessa aivohalvauksen jälkeen (ks. taulukko 1).

\section{Tanssin vaikutukset AVH-kun- toutuksessa}

Aineistossa tanssin vaikutukset ilmenivät niin fyysisessä, kognitiivisessa kuin psykososiaalisessa toimintakyvyssä. Fyysisen toimintakyvyn osalta tutkimuksissa korostui erityisesti tanssin myönteinen vaikutus tasapainoon ja kävelyyn. Lisäksi tutkimuksissa havaittiin positiivisia vaikutuksia fyysiseen kestävyyteen (Hackney ym. 2012; Beaudry ym. 2019a). Tutkimuksissa tanssin todettiin edistävän myös kehon asennon ylläpitämistä ja sen vaihdoksia (esim. istuminen, ylös nouseminen ja esineiden käsittely). Lisäksi tutkimuslöydöksiä raportoitiin lisääntyneestä nivelten liikkuvuudesta, lihasvoimasta ja vähentyneestä lihastonuksesta sekä

\begin{tabular}{|c|c|c|c|c|}
\hline $\begin{array}{l}\text { Tekijä(t) ja } \\
\text { julkaisuvuosi }\end{array}$ & Otsikko & Menetelmä & $\begin{array}{l}\text { Tutkittavien määrä (N), } \\
\text { ikä ja AVH:n } \\
\text { sairausvuodet }\end{array}$ & Maa \\
\hline $\begin{array}{l}\text { Beaudry, Fortin ja } \\
\text { Rochette } 2019 a\end{array}$ & $\begin{array}{l}\text { Adapted Dance Used in Subacute } \\
\text { Rehabilitation Post-Stroke: } \\
\text { Impacts Perceived by Patients, } \\
\text { Relatives and Rehabilitation } \\
\text { Therapists. }\end{array}$ & $\begin{array}{l}\text { Kvalitatitivinen tutkimus, } \\
\text { interventio ( } 55 \text { min, } \\
\text { vuoroviikoin, } 10 \text { vilkkoa) } \\
\text { ja puolistrukturoitu } \\
\text { haastattelu }\end{array}$ & $\begin{array}{l}\mathrm{N}=\text { yhteensä } 22 \text { (12 } \\
\text { terapeuttia, } 4 \text { omaista, } 6 \\
\text { sairastunutta) } \\
\text { lkä: } 59-86 \mathrm{v} \text {. } \\
\text { (sairastuneet) } \\
\text { Keskivertoikä: } 71 \mathrm{v} . \\
\text { (sairastuneet) } \\
\text { Aivohalvauksesta 4-25 } \\
\text { pä̀ää }\end{array}$ & Kanada \\
\hline $\begin{array}{l}\text { Beaudry, Fortin, ja } \\
\text { Rochette 2019b }\end{array}$ & $\begin{array}{l}\text { Adapted-Dance Intervention for } \\
\text { Subacute Rehabilitation Post- } \\
\text { Stroke: 'WHAT' and 'HOW'. }\end{array}$ & $\begin{array}{l}\text { Kvalitatilivinen tutkimus, } \\
\text { focus group } \\
\text {-haastattelu, observointi } \\
\text { ja intervention } \\
\text { analysointi }\end{array}$ & $\begin{array}{l}\mathrm{N}=18 \\
\text { kuntoutusterapeuttia }\end{array}$ & Kanada \\
\hline Chen ym. 2018 & $\begin{array}{l}\text { Therapeutic Effects of Sensory } \\
\text { Input Training on Motor Function } \\
\text { Rehabilitation After Stroke. }\end{array}$ & Kirjallisuuskatsaus & & Kiina \\
\hline $\begin{array}{l}\text { Demers ja } \\
\text { McKinley } 2015\end{array}$ & $\begin{array}{l}\text { Feasibility of Delivering a Dance } \\
\text { Intervention for SubAcute Stroke } \\
\text { in a Rehabilitation Hospital } \\
\text { Setting. }\end{array}$ & $\begin{array}{l}\text { Kvalitatiivinen tutkimus, } \\
\text { interventio (vuoroviikoin } \\
45 \mathrm{~min}, 4 \mathrm{vk} \text { ) }\end{array}$ & $\begin{array}{l}\text { lkä: } 47-78 \mathrm{v} . \\
\text { keskivertoikä: } 63.7 \mathrm{v} . \\
\text { subakuutti vaihe (1-6kk) }\end{array}$ & Kanada \\
\hline $\begin{array}{l}\text { Dhami, Moreno ja } \\
\text { DeSouza } 2015\end{array}$ & $\begin{array}{l}\text { New Framework for } \\
\text { Rehabilitation - Fusion of } \\
\text { Cognitive and Physical } \\
\text { Rehabilitation: The Hope for } \\
\text { Dancing. }\end{array}$ & Kirjallisuuskatsaus & & Kanada \\
\hline Gregorym. 2020 & $\begin{array}{l}\text { Structuring Community-Based } \\
\text { Adapted Dance Programs for } \\
\text { Persons Post-Stroke. }\end{array}$ & $\begin{array}{l}\text { Kvalitatilivinen tutkimus, } \\
\text { focus group -keskustelu } \\
\text { (aivohalvaukseen } \\
\text { sairastuneiden, } \\
\text { tanssinopettajien ja } \\
\text { fysioterapeuttien } \\
\text { kesken) }\end{array}$ & $\begin{array}{l}\mathrm{N}=9 \text { (sairastuneet) } \\
\mathrm{lkäa}: 43 \text { - } 80 \text { v. (sairastuneet) } \\
\text { Aivohalvauksesta } 6.8 \\
\text { divohalvauksesta }\end{array}$ & Kanada \\
\hline Hackney ym. 2012 & $\begin{array}{l}\text { Application of Adapted Tango as } \\
\text { Thera-peutic Intervention for } \\
\text { Patients with Chronic Stroke. }\end{array}$ & $\begin{array}{l}\text { Tapaustutkimus, } \\
\text { interventio }(1.5 \mathrm{~h} \times 2 \mathrm{vk}, \\
12 \text { vilkon ajan) }\end{array}$ & $\begin{array}{l}\mathrm{N}=1 \\
\text { lkă: } 73 \mathrm{v} \text {. } \\
\text { Aivohalvauksesta } 13 \text { vuotta }\end{array}$ & USA \\
\hline $\begin{array}{l}\text { Patterson ym. } \\
\text { 2018a }\end{array}$ & $\begin{array}{l}\text { A Dance Program to Improve Gait } \\
\text { and Balance in Individuals with } \\
\text { Chronic Stroke. }\end{array}$ & $\begin{array}{l}\text { Kvantitatiivinen } \\
\text { tutkimus } \\
\text { interventio ( } 2 \times v k, 10 \\
\text { viikon ajan) }\end{array}$ & $\begin{array}{l}\text { Keskivertoikä: } 62.3 \mathrm{v} \text {. } \\
\text { Aivohalvauksesta } 6.4 \\
\text { vuotta }\end{array}$ & Kanada \\
\hline $\begin{array}{l}\text { Patterson ym. } \\
2018 \mathrm{~b}\end{array}$ & $\begin{array}{l}\text { Dance for the Rehabilitation of } \\
\text { Balance and Gait in Adults with } \\
\text { Neurological Conditions Other } \\
\text { than Parkinson's Disease: A } \\
\text { systematic review. }\end{array}$ & $\begin{array}{l}\text { Systemaattinen } \\
\text { kirjallisuuskatsaus }\end{array}$ & $\begin{array}{l}\text { Ikä: } 43-73 \mathrm{v} \text {. } \\
\text { (7/9 tutkimuksesta raportoi } \\
\text { iän) }\end{array}$ & Kanada \\
\hline Pohjolaym. 2019 & $\begin{array}{l}\text { The Potential of Dance Art in } \\
\text { Recovery from a Stroke: A Case } \\
\text { Study. }\end{array}$ & $\begin{array}{l}\text { Kvalitativinen } \\
\text { tapaustutkimus, } \\
\text { stimuloitu muistiin } \\
\text { palauttamismenetelmä } \\
\text { ja syvähaastattelu }\end{array}$ & $\begin{array}{l}\mathrm{N}=1 \\
\mathrm{k} \mathrm{ka}=\mathrm{n} .50 \mathrm{v} . \\
\text { Aivohalvauksesta } 2 \text { vuotta }\end{array}$ & Suomi \\
\hline $\begin{array}{l}\text { Thomberg, } \\
\text { Josephsson ja } \\
\text { Lindquist } 2014\end{array}$ & $\begin{array}{l}\text { Experiences of Participation in Rh } \\
\text { ythm and Movement Therapy } \\
\text { After Stroke. }\end{array}$ & $\begin{array}{l}\text { Kvalitatilivinen tutkimus, } \\
\text { haastattelu }\end{array}$ & $\begin{array}{l}\mathrm{N}=17 \\
\text { Ikä: 38-76v. } \\
\text { Aivohalvauksesta 2-16 } \\
\text { vuotta }\end{array}$ & Ruotsi \\
\hline
\end{tabular}

Taulukko 1. Valitut artikkelit.

liikkeiden hallinnasta ja niiden koordinoinnista (Hackney ym. 2012; Beaudry ym. 2019a).

Fyysisten vaikutuksen ohella myös kognitiivinen toimintakyky lisääntyi. Tanssiminen mahdollistaa AVH-kuntoutuksessa liikesarjojen opettelun (Beaudry ym. 2019b). Esimerkiksi liikesarjan tai koreografian opettelu sallii tanssiaskelten toistamisen, joka tuo haastetta muistamiselle ja kehittää sitä (Demers ja McKinley 2015). Musiikki oli olennainen osa kognitiivisen toimintakyvyn edistämistä tutkimuksissa, sillä tanssiminen musiikin säestämänä aktivoi useita eri alueita aivoissa, kuten esimerkiksi pikkuaivojen etummaisia osia, tyvitumakkeita ja aivokuorta. Tanssiminen vaatii kuuntelun ja käsittelyn ohella myös liikku- 
mista musiikin tahtiin. Näin ollen tanssin ja musiikin yhdistetty terapian muoto voi olla tehokas kognitiivisen stimulaation lähde (Dhami ym. 2015, 6). Onkin esitetty, että moniaistisuus on ratkaisevassa roolissa motorisessa kuntoutuksessa, sillä aistijärjestelmän vioittuminen voi vaikuttaa motorisiin toimintoihin. Näin ollen aistihavaintoja pitäisi korostaa aivohalvauksen jälkeisessä kuntoutuksessa, sillä aistimotorinen lähestymistapa on tehokkaampaa kuin perinteiset motoriikkaan orientoituneet kuntoutustavat (Chen ym. 2018, 3-4).

Myös psykososiaalisen toimintakyvyn kehittyminen oli keskeisessä osassa tutkimusaineistossa: yhteisöllisyys, minäpystyyyys ja osallisuus olivat korostetusti esillä. Ilman aktiivista osallistumista kuntoutukseen, optimaalisen palautumisen todennäköisyys on pieni. Tästä syystä sitoutumisella, motivaatiolla, luottamuksella, itsenäisyydellä ja sosiaalisilla suhteilla on suuri merkitys kuntoutuksessa (Beaudry ym. 2019a, 7). Tyytyväisyys ja osallistuvuus tanssi-interventioissa sekä lisääntynyt subjektiivinen hyvinvointi ja tanssista saatu ilo voivat sitouttaa osallistumisessa interventioon, ja täten mahdollisesti vaikuttaa kokonaisuudessaan kuntoutusmotivaation. Lisäksi minäpystyvyyden, hyvinvoinnin, mielialan ja sosiaalisuuden kohentuminen saattavat vaikuttaa osallistuneisuuteen, kun uupumuksen tunne jää näiden varjoon (Hackney ym. 2012; Patterson ym. 2018a; Beaudry ym. 2019a, 8-9).

Erityisesti sovelletun tanssin ryhmäinterventio näyttäisi edistävän yhteisöllisyyden kokemista (Beaudry ym. 2019a, 9). Tanssiminen voi rohkaista myös merkityksellisiin sosiaalisiin suhteisiin yhteisön sisällä ja luoda näin tunteen yhteisöllisyydestä sekä itsehyväksynnästä (Gregor ym. 2020). Tällaisessa ryhmässä osallistujat voivat tuntea olonsa turvalliseksi ja itsevarmaksi. Se rohkaisee muutoinkin arjen sosiaalisissa tilanteissa: esimerkiksi ujoudesta huolimatta juttelemaan ihmisille aiempaan tilanteeseen verrattuna enemmän (Beaudry ym. 2019a, 6-8). Lisäksi tanssi voi olla merkityksellinen kommunikoinnin väline henkilöille, joilla on afasia (Pohjola ym. 2019; Gregor ym. 2020).

AVH-kuntoutujia tulisi myös kannustaa palaamaan merkitykselliseen elämään ja aktiviteetteihin (Thornberg ym. 2014). Osallistumista kehotuntemusta lisäävään aktiviteettiin, joka on myös haastava, pidettiin arvokkaana. Se lisäsi kyvykkyyttä suoriutua monimutkaisista aktiviteeteista ja vaikutti myönteisesti minäkuvaan. Tanssiminen johti toimeen tulemiseen muuttuneen kehon kanssa ja sen kotoisaksi tuntemiseen (Thornberg ym. 2014, 1869-1873). Minäpystyvyys nousi vahvasti esille myös Pohjolan ym. (2019) ja Beaudryn ym. (2019a) tutkimuksissa. Minäpystyvyyden tunnetta pidetäänkin tärkeänä aivohalvauksen vammautumisen jälkeen, ja se voi vaikuttaa itsesäätelyyn kognitiivisella, affektiivisella ja käyttäytymisen tasoilla. Tämän vuoksi on oleellista tutkia sovelletun tanssin vaikutuksia psykologiseen rakenteeseen, koska etenkin luottamus omaan kyvykkyyteen sekä motivaatioon raportoitiin kestäneen edelleen kolmen kuukauden kuluttua intervention päättymisen jälkeen (Beaudry ym. 2019a, 5). Sisäinen motivaatio löydettiin myös tärkeänä Pohjolan ym. (2019) tutkimuksessa, jossa ilmeni tanssin mahdollisuus kehittää itsetuntoa, itseluottamusta ja toimijuutta.

\section{Tanssituntien rååtålo̊iminen}

Tanssityylit vaihtelivat tutkimuksissa (esim. jazz, merengue, nykytanssi, baletti, kansantanssi, tango, improvisaatio) ja joissakin tutkimusinterventioissa oli myös yhdistettynä useampia lajeja (Hackney ym. 2012; Demers ja McKinley 2015; Patterson ym. 2018a, 2018b; Pohjola ym. 2019). Kestoltaan tanssitunnit vaihtelivat 45 min-120 min. Keskeistä oli useiden taukojen pitäminen ja väsymisen huomioiminen. Ryhmät kokoontuivat useimmiten kahdesti viikossa (Hackney ym. 2012; Demers ja McKinley 2015; Patterson ym. 2018a; Beaudry ym. 2019b; Gregor ym. 2020). Tanssitunnin rakenne koostui esimerkiksi lämmittelystä, tekniikkaharjoitteista, 
improvisaatiosta, lyhyestä liikeyhdistelmästä ja loppuverryttelystä (Demers ja McKinley 2015, 5); yksin, pareittain ja ryhmässä (Patterson ym. 2018; Beaudry ym. 2019b). Tanssitunti tulisi suunnitella edistämään osallistujien toimintakykyä. Osallistujien kykyihin ja tavoitteisiin perustuva tanssitunnin rakenne tulisi olla johdonmukainen ja sisältää ennustettavuuden ja vaihtelevuuden elementtejä motivoimisen ja kehityksen tueksi. Tanssitunnin rakenteen tulisi myös huomioida sydän- ja verenkiertoelimistön terveys sekä alttius väsymykselle. Erityisesti tasapainon harjoittamista (Gregor ym. 2020, 9) olisi hyvä sisällyttää tanssituntiin. Tanssiharjoitteet tulisivat olla soveltuvia istuen tai seisten (Hackney ym. 2012; Demers ja McKinley 2015; Patterson ym. 2018a) tai pyörätuolissa (Beaudry ym. 2019b) istuen. Avustajia ja apuvälineitä voidaan käyttää tunneilla, jotta kaatumisriskiä ja loukkaantumisen mahdollisuutta voi vähentää (Gregor ym. 2020, 7-9).

Myös koskettaminen ja musiikki ovat usein osa tanssituntia. Kliininen tutkimusnäyttö on todistanut aistitoimintojen ja motoristen toimintojen läheisen suhteen (Chen ym. 2018, 2). On havaittu, että kevyt kosketus voi edistää asennon vakautta, mikä voi johtua aktiivisten liikkeiden vahvistetusta tietoisuudesta (Kiemel ym. 2002). Tämä linkittyy esimerkiksi paritanssilajien tarjoamaan tukeen, ja kosketusta voi myös hyödyntää harjoitteiden suunnittelussa. Esimerkiksi moniaistisessa stimulaatioterapiassa käytetään nopeaa harjausta ja kevyttä kosketusta ihoa vasten tai lihasten taputtelua motivoimaan tai hillitsemään neurolihasliitoksen reaktiota (engl. neuromuscular reaction), jonka lisäksi voidaan käyttää puristamista tai venyttelyä lievittämään lihaskouristuksia (Chen ym. 2018, 3). Kosketuksen ohella myös musiikki koettiin aineistossa tärkeänä tekijänä emootioiden kehonhallintaprosessissa ja monimutkaisten aktiviteettien muistamisessa ja niiden käsittelemisessä. Musiikki teki liikkeiden tekemisestä ja esittämisestä myös helpompaa ja hauskempaa (Thornberg ym. 2014, 1871).
Erityisesti mielimusiikin käyttöä suositeltiin useissa tutkimuksessa (Demers ja McKinley 2015; Gregor ym. 2020).

Suurimmassa osassa tutkimuksia tanssi-intervention ohjaajana ei ollut tanssipedagogi, vaan esimerkiksi kuntoutusterapeutti (Beaudry ym. 2019a), henkilökohtainen valmentaja (Hackney ym. 2012) tai toimintaterapeutti (Demers ja McKinley 2015). Beaudryn ym. tutkimuksen mukaan voikin siis olla sinänsä rajoite, että intervention ohjaa fysioterapeutti tai toimintaterapeutti eikä tanssinopettaja (Beaudry ym. 2019b). Aineistoon valikoituneista tutkimuksista vain yksi (Gregor ym. 2020) tutkimusjulkaisu keskittyi nimenomaan siihen, millainen soveltuvan intervention sekä tanssinopettajan tulisi olla; esteettömän ja turvallisen ympäristön sekä tunnin sujuvuuden ohella keskeistä oli myös tanssinopettajan pedagogiset taidot ja opetusfilosofia. Tanssiopettajalla tulee olla korostetusti substanssiosaamista ja kykyä sen soveltamiseen yksilöllisesti. Lisäksi tanssinopettajan tulisi olla rohkaiseva, joustava ja huomaavainen luomaan turvallinen ja tervetullut ympäristö. Turvallisen ympäristön luominen vaatii sekä fyysisen ja emotionaalisen näkökulman helpottamaan yhteyksien luomista osallistujien kesken ja tuntemaan itsensä luottavaisemmaksi. AVH-tanssin kontekstissa tanssinopettajan opetusfilosofian tulisi kohdistua näkemykseen, jossa jokainen tanssija saa olla vapaa ja ainutlaatuinen liikkeissään sen sijaan, että keskityttäisiin tanssijoiden rajoituksiin (Demers ja McKinley 2015; Gregor ym. 2020). Keskeistä olisi löytää yhteys muuttuneeseen kehoon ja tuoda esille kehon uudet mahdollisuudet ja sen kywykkyys (Pohjola ym. 2019).

\section{Pohdinta}

Tämän artikkelin tavoitteena on ollut tarkastella tieteelliseen näyttooön perustuvaa tutkimusta tanssin käyttämisestä AVH-kuntoutuksessa ja siihen liittyvää tanssipedagogiikkaa. Kirjallisuuskatsaukseen valikoituneista tutkimuksista ilmeni, että tanssi on 
käyttökelpoinen ja soveltuva lääketieteellistä kuntoutusta täydentävä menetelmä AVH-kuntoutujille: tanssi edistää psykososiaalista, kognitiivista ja fyysistä toimintakykyä. Tanssitunnin tulisi seurata osallistujien tavoitteita ja heidän mieltymyksiään. Tunnin rakenne tulisi olla johdonmukainen ja sisältää ennustettavuuden ja vaihtelevuuden elementtejä. Tutkimukset ehdottivat, että optimaalinen tanssitunti olisi yhdestä kahteen tuntia kestoltaan ja toteutuisi kaksi kertaa viikossa noin kolmen kuukauden (1. kymmenen viikon) ajan. Tanssitunnin täytyisi sisältää taukoja. Tanssityyli voi vaihdella ja tanssia voi sekä partnerin kanssa tai ilman. Tutkimustulosten perusteella tanssitunnin tulisi sisältää sekä improvisaatiota että opeteltavia liikeyhdistelmiä, koska improvisaation ja kehotietoisuuden avulla mahdollistettiin yhteyden löytäminen muuttuneeseen kehoon, kun taas liikeyhdistelmien opetteleminen haastaa muistia. Erityisesti taidetanssi rohkaisi kehon uusiin mahdollisuuksiin ja kehon kyvykkyyteen.

Fyysiset harjoitustavoitteet tulisi kohdentaa erityisesti tasapainoon ja askellukseen. Lisäksi toiminnallista liikkuruutta olisi hyvä lisätä. Subakuutissa aivohalvauksen kuntoutumisen vaiheessa tasapainon harjoittelussa vaikeustason nostaminen on tärkeää, koska kehittyminen etenee tässä vaiheessa eniten. Kuitenkin liian vaikeita tasapainoliikkeitä täytyisi välttää, koska silloin tasapainon varmuus saattaa kärsiä. Osallistujilla täytyisi olla mahdollisuus edetä tanssiliikkeiden haastavuuden kanssa yksilökohtaisesti ja suorittaa ne omalla tavalla huomioimalla omat fyysiset rajoitukset. Motivaation säilyttämiseksi olisi hyvä silti lisätä tanssiliikkeiden haastavuutta yksilöllisesti. Tulosten mukaan myös kosketus voi parantaa asennon vakautta ja motivoida tai hillitä hermolihasliitoksen reaktiota.

Tanssi tukee erityisellä tavalla myös itsepystyvyyttä ja kehittää sosiaalisia suhteita. Lisäksi tanssi kohentaa mielialaa. Tanssin nautinnollisuus voi myös edesauttaa ja helpottaa fyysisten toimintojen edistämistä; kuntoutuja voi kehittää fyysistä toimintakykyään ilman puurtamisen tunnetta. Tanssi voi rohkaista myös laajempiin liikelaajuuksiin ja haastavampiin liikkeisiin, joihin kuntoutuja ei edes uskoisi itse pystyvän. Lisäksi tanssilla voi olla syvällisempi merkitys fyysisen toimintakywyn edistämisen lisäksi, koska sen avulla kuntoutuja voi löytää uudelleen paikkansa maailmassa (ks. esim. Beaudry ym. 2019b; Pohjola ym. 2019, 40).

Toistaiseksi tanssipedagogiikkaa sovelletussa tanssissa ja AVH -kuntoutuksessa on tutkittu vähän ja tutkimusaineistossakin ilmeni vain yksi tutkimus ko. aiheesta. Kun esimerkiksi puhutaan ns. sovelletusta tanssista, «sovellettu» -käsite viittaa tanssin sisältöön ja pedagogiikkaan. Esimerkiksi vain toisen näistä soveltaminen ei riitä varmistamaan, että tanssi-intervention toiminta perustuu todella sovelletun tanssin kontekstiin ja on relevanttia AVH-kuntoutukselle. Taiteellinen ludinen (so. pelinomainen ja leikkisä) tanssin pedagogiikka eroaa usein tyypillisistä kuntoutuksen liikeharjoituksista ja saattaa selittää suuren osan kiinnostuksesta osallistua tanssi-interventioihin. Myös hienovarainen somaattis-sensitiivinen tanssipedagogiikka voi tarjota myös uudenlaisen keinon kuntoutuksen osallisuuden edistämiseen (Beaudry ym. 2019b, 294).

Kirjallisuuskatsaukseen valikoituneet tutkimukset ovat tuloksiltaan samankaltaisia, kuin tanssi -ja liiketerapian liittyen tehty Kelan selvitys vuodelta 2016. Siinä Kela suosittelee tanssi- ja liiketerapiaa kuntoutusmenetelmänä, ja arvioinnin mukaan tanssi soveltuu Kelan järjestämän lääkinnällisen kuntoutuksen terapiamuodoksi (Matinheikki-Kokko ym. 2016). Tämän kirjallisuuskatsauksen aineisto kuitenkin esittää implisiittisesti, että sinänsä mikään tanssityyli ei ole toistaan sopivampi, vaan tanssituntien yhteneväisyydet esteettömyydessä, saavutettavuudessa, tavoitteissa ja ohjauksessa ovat keskeisiä. Erityisesti kuntoutujan oma aktiivisuus ja kiinnostus kuntoutumistaan kohtaan ovat kuntoutumisen avaintekijöitä. Aineiston tutkimuksista havaitut tyytyväisyys ja osallistuvuus interventioon herättävät huomion. Myös tanssi voi 
mahdollisesti vaikuttaa kokonaisuudessaan kuntoutukseen osallistumiseen. Fyysisen, psykologisen ja kognitiivisen toimintakyvyn kehittyminen voi lievittää myös masentuneisuutta ja ahdistusta, jolloin osallistuvuus kuntoutukseen voi kasvaa. Nämä johtopäätökset voivat puhua sen puolesta, että tanssi voisi vastata kokonaisvaltaisesti uuden terapiamuodon tarpeeseen. Tutkimusaihe on tuore ja hakukriteerejä täyttäviä tutkimusartikkeleita ei ole vielä paljon. Artikkeliin valikoitu tutkimusaineisto on siis pieni ja rajattu otos vielä varsin nuoresta tutkimusilmiöstä. Ensinnäkin valittuja tietokantoja oli rajattu määrä (kolme) ja artikkeleja kertyi yhteensä 11. Toiseksi aineiston keruussa painotettiin avointa saatavuutta sekä vertaisarvioituja tieteellisiä artikkeleja (so. kirjat rajattiin pois). Lisäksi aineistoon valikoituneet tutkimukset olivat keskenään myös erilaisia lähestymistavoiltaan ja metodeiltaan. Tutkimukset eri menetelmineen kuitenkin olivat keskenään samansuuntaisia ja näin ollen vahvistavat toisiaan. Katsaukseen valikoituneet tutkimukset tarkastelivat eritoten tanssin terveysvaikutuksia. Tanssin ontologinen, subjektiivinen merkitystodellisuus, oli aineiston tutkimuksissa vähäisempää. Myös kokemusperäinen tieto ruumiillisuudesta oli niukkaa. Jatkossa tulisikin kohdentaa huomio myös itse taiteeseen ja sen kokemiseen, ei vain sen terveyshyötyihin. Lisäksi kirjallisuuskatsaus osoitti, että tanssipedagoginen tutkimus aiheessa on toistaiseksi vielä hyvin vähäistä: jatkotutkimuksellisesti ajatellen tulisikin kiinnittää huomiota myös sovelletun tanssi-intervention pedagogiikkaan ja tanssin ontologiaan.

Tanssiminen on turvallinen, helposti implementoitavissa oleva ja kustannustehokas lääketieteellistä kuntoutusta täydentävä hoitomuoto moniammatillisessa kontekstissa. Tämän artikkelin aineisto kannustaa aktiivisesti hyödyntämään tanssinopettajien ammatillista osaamista laajemmin myös ns. perinteisen taiteen perusopetuksen ulkopuolelle. Tämä edistäisi niin kulttuurista oikeutta tanssiin, inklusiivisuutta ja osallisuutta (ks. esim. Lehikoinen 2017; Fancourt ja
Finn 2019). Tanssinopetuksen laajentuneeseen työkenttään ja sen sisältämiin mahdollisuuksiin sekä sen asettamiin vaateisiin tulisi vastata laajentamalla tanssinopettajien koulutusta ja myös käsitystä oman opettajuuden ulottuvuudesta tanssitaiteen kentällä.

\section{Låhteet}

Aivoliitto. 2020. Aivoverenkiertohäiriö. Turku: Aivoliitto. [sähköinen tietoaineisto]. Haettu 15.4.2020. https://www.aivoliitto.fi/aivoverenkiertohairio/ faktat/.

Beaudry, Lucie, Sylvie Fortin, ja Annie Rochette, 2019a. «Adapted Dance used in Subacute Rehabilitation Poststroke: Impacts Perceived by Patients, Relatives and Rehabilitation Therapists.» Disability and Rehabilitation, 1-10. doi:10.1080/09638288.2019.1581845.

Beaudry, Lucie, Sylvie Fortin, ja Annie Rochette, 2019b. «Adapted-Dance Intervention for Subacute Rehabilitation Post-Stroke: 'WHAT' and 'HOW'.» Research in Dance Education 20 (3): 279-296. doi:10.1080/14647893.2019.1644617.

Braun, Virginia, ja Victoria Clarke. 2006. «Using Thematic Analysis in Psychology.» Qualitative Research in Psychology 3 (2): 77-101. doi:10.1186/1477-7525-5-63.

Chen, Xiaowei, Fuqian Liu, Zhaohong Yan, Shihuan Cheng, Xunchan Liu, He Li, ja Zhenlan Li. 2018. «Therapeutic Effects of Sensory Input Training on Motor Function Rehabilitation After Stroke.» Medicine 97 (48): e13387. doi:10.1097/ MD. 0000000000013387.

Demers, Marika, ja Patricia McKinley. 2015. «Feasibility of Delivering a Dance Intervention for SubAcute Stroke in a Rehabilitation Hospital Setting.» International Journal of Environmental Research and Public Health 12 (3): 3120-3132. doi:10.3390/ijerph120303120. 
Dhami, Prabhjot, Sylvain Moreno, Joseph DeSouza, ja Joseph F X. Desouza. 2015. «New Framework for Rehabilitation-Fusion of Cognitive and Physical Rehabilitation: The Hope for Dancing.» Frontiers in Psychology 5: 1478. doi:10.3389/ fpsyg.2014.01478.

Fancourt, Daisy, ja Saoirse Finn. 2019. «What is the Evidence on the Role of the Arts in Improving Health and Well-Being?» A Scoping Review. Copenhagen: WHO Regional Office for Europe. Haettu 26.05.2020. https://apps.who.int/iris/bitstream/ha ndle/10665/329834/9789289054553-eng.pdf.

Gregor, Sarah, Julie Vaughan-Graham, Aaron Wallace, Hilary Walsh, ja Kara K. Patterson. 2020. «Structuring Community-Based Adapted Dance Programs for Persons Post-Stroke: A Qualitative Study.» Disability and Rehabilitation: 1-11. doi:10.1080/09638288.2019.1708978.

Hackney, Madeleine E., Courtney Hall, Katharina V. Echt, ja Steven Wolf. 2012. «Application of Adapted Tango as Therapeutic Intervention for Patients with Chronic Stroke.» Journal of Geriatric Physical Therapy 35 (4), 206-217. doi:10.1519/ JPT.0b013e31823аe6ea.

Hotus (Hoitotyön tutkimussäätiö). (N.d.). Tutkimustiedon hakeminen. [sähköinen tietoaineisto]. Haettu 10.4.2020. https://www.hotus.fi/tutkimustiedon-hakeminen/.

Jaakonaho, Liisa. 2017. «Encountering and Embodying Difference through Dance: Reflections on a Research Project in a Primary School in Finland.» Teoksessa Stephanie Burridge ja Charlotte Svendler Nielsen (toim.) Dance, Access and Inclusion: Perspectives on Dance, Young People and Change, 65-69. Oxon: Routledge. https:// www.taylorfrancis.com/books/9781317201588.
Kangasniemi, Mari, Kati Utriainen, Sanna-Mari Ahonen, Anna-Maija Pietilä, Petri Jääskeläinen, ja Eeva Liikanen. 2013. «Kuvaileva Kirjallisuuskatsaus: Eteneminen Tutkimuskysymyksestä Jäsennettyyn Tietoon» Hoitotiede 25 (4): 291-301. http://search.proquest.com/ docview/1469873650/.

Käypä hoito -suositus. 2020. «Aivoinfarkti ja TIA. Suomalaisen Lääkäriseuran Duodecimin ja Suomen Kardiologisen Seuran asettama työryhmä. Helsinki: Suomalainen Läk̈äriseura Duodecim». [sähköinen tietoaineisto]. Haettu 27.4.2020. https:// www.kaypahoito.fi/hoi50051.

Lehikoinen, Kai. 2017. «Cultural Rights, Well-being and Democracy in Elderly Care: The Dance Ambassadors as a Case Study.» Nordic Journal of Dance 8 (2): 30-41.

Lehikoinen, Kai. 2019. «Dance in Elderly Care: Professional Knowledge.» Journal of Dance Education 19 (3): 108-116. doi:10.1080/15290824.201 8.1453612 .

Lewis, Carine, Lucy E. Annett, Sally Davenport, Amelia A. Hall, ja Peter Lovatt. «Mood Changes Following Social Dance Sessions in People with Parkinson's Disease». Journal of Health Psychology 21 (4): 483-492. doi:10.1177/1359105314529681.

Lossing, Ana, Mary Moore, ja Micah Zuhl. 2017. «Dance as a treatment for neurological disorders». Body, Movement and Dance in Psychotherapy, 12 (3), 170-184. doi:10.1080/17432979.2016.12 60055 .

Matinheikki-Kokko, Kaija, Ulla Härkönen, Minna Muhonen, ja Salla Sipari. 2016. «Tanssi- ja liiketerapia kuntoutusmuotona: Kuntoutuksen vaikutukset ja hyödyt kirjallisuuskatsauksen asiakaskokemusten ja ammattilaisten kokemusten valossa». Kelan julkaisuja. [sähköinen tietoaineisto]. Haettu 26.5.2020. https://helda.helsinki.fi/bitstream/handle/10138/164471/Tyopapereita99. pdf?sequence $=1$. 
Patterson, Kara K., Jennifer S. Wong, Thi-Ut Nguyen, ja Dina Brooks. 2018a. «ADance Program to Improve Gait and Balance in Individuals with Chronic Stroke: A Feasibility Study.» Topics in Stroke Rehabilitation 25 (6): 410-416. doi:10.1080/10749 357.2018.1469714.

Patterson, Kara K., Jennifer S. Wong, Eric C. Prout, ja Dina Brooks. 2018b. «Dance for the Rehabilitation of Balance and Gait in Adults with Neurological Conditions other than Parkinson's Disease: A Systematic Review.» Heliyon 4 (3): e00584. doi:10.1016/j.heliyon.2018.e00584.

Pohjola, Hanna, Anne Vaajoki, ja Tarja Välimäki. 2020. «Art Intervention Among Finnish Older People and Their Caregivers: Experiences of Art Pedagogies.» Health and Social Care in the Community. (Published as Early View). doi:10.1111/hsc.13003.

Pohjola, Hanna, Paavo Vartiainen, Pasi Karjalainen, ja Vilma Hänninen. 2019. «The Potential of Dance Art in Recovery From a Stroke: A Case Study.» Nordic Journal of Dance 10 (1/2): 32-43.

Rios Romenets, Silvia, Julius Anang, Seyed-Mohammad Fereshtehnejad, Amelie Pelletier, ja Ronald Postuma. 2015. «Tango for Treatment of Motor and Non-motor Manifestations in Parkinson's Disease: A Randomized Control Study.» Complementary Therapies in Medicine 23 (2): 175184. doi:10.1016/j.ctim.2015.01.015.

\section{BIOGRAPHY}

Camilla Björklund is a dance teacher and sports instructor. She has a bachelor's degree in dance pedagogy from Savonia University of Applied Sciences. This article is based on her thesis. camillamariabjorklund@gmail.com
Robinson, Robert G, ja Ricardo E. Jorge. 2016. «Post-Stroke Depression: A Review.» American Journal of Psychiatry. 2016;173 (3): 221-231. doi:10.1176/appi.ajp.2015.15030363.

Salminen, Ari. 2011. «Mikä 'kirjallisuuskatsaus? Johdatus kirjallisuuskatsauksen tyyppeihin ja hallintotieteellisiin sovelluksiin.» Vaasan yliopiston julkaisuja. Opetusjulkaisuja 62. [sähköinen tietoaineisto] Haettu 26.5.2020. https://www.univaasa.fi/ materiaali/pdf/isbn_978-952-476-349-3.pdf.

Shanahan, Joanne, Meg E. Morris, Orfhlaith N. Bhriain, Jean Saunders, ja Amanda M. Clifford. 2015. «Dance for People with Parkinson Disease: What is the Evidence Telling Us?» Archives of Physical Medicine and Rebabilitation 96 (1): 141-153. doi:10.1016/j.apmr.2014.08.017.

Sharp, Kathryn ja Jonathan Hewitt. 2014. «Dance as an Intervention for People with Parkinson's Disease: A Systematic Review and Meta-Analysis.» Neuroscience \& Biobehavioral Reviews 47: 445-456. doi:10.1016/j.neubiorev.2014.09.009.

Thornberg, Kerstin, Staffan Josephsson, ja Ingrid Lindquist. 2014. «Experiences of Participation in Rhythm and Movement Therapy After Stroke.» Disability and Rebabilitation, 36 (22): 18691874. doi:10.3109/09638288.2013.876107.

Tuomi, Jouni ja Anneli Sarajärvi. 2018. Laadullinen tutkimus ja sisällönanalyysi. Helsinki: Tammi.

Hanna Pohjola (Doctor of Arts in Dance) is a Finnish dance artist and dance teacher. Her doctoral dissertation, which addressed the identity of the injured former contemporary dancer, was published in 2012. In addition to her master's and doctoral degrees in dance, Pohjola has a bachelor's and a master's degree in health sciences (exercise medicine). She has also graduated as a physiotherapist. 